DOI 10.4467/25439561KSR.18.005.9363

AgNIESZKA ZiOŁOWICZ (D) https://orcid.org//0000-0002-5335-1125

Uniwersytet Jagielloński

Kraków

\title{
NORWIDOWSKIE MIARY I OGLĄDY HEROIZMU
}

\author{
NORWID'S MEASURE AND PERCEPTION OF HEROISM
}

\section{Streszczenie}

Artykuł zawiera interpretację Norwidowskiej koncepcji heroizmu. Nawiązuje do różnych obszarów dzieła Norwida, do jego utworów lirycznych, epickich i dramatycznych, a także do wypowiedzi publicystycznych, krytycznoliterackich oraz epistolarnych. W centrum rozważań znajduje się kwestia bohatera kulturowego, którego znaczenie w myśli i wyobraźni pisarza przedstawione zostało $\mathrm{w}$ sekwencji analiz poświęconych przewodnikom ludzkości (Prometeusz, Mojżesz, Argonauci, Jezus Chrystus), bohaterom narodowym (Krakus, Wanda, bohaterowie powstania styczniowego) oraz poetom (legenda Tyrteusza). Kontekst dla powyższych analiz stanowi antropologiczna refleksja epoki, Norwidowska koncepcja osoby, filozoficzne i religijne wykładnie postawy heroicznej, jej kulturowe wzorce. Zarysowane przez Norwida rozumienie heroizmu okazuje się na tym tle w pełni oryginalne, choć zarazem wynika $\mathrm{z}$ wielostronnego dialogu z wybranymi wątkami tradycji heroicznej. O swoistości Norwidowskiej wykładni zjawiska świadczą: akcentowanie znaczenia kulturowego i etosowego każdego aktu heroicznego, eksponowanie heroizmu ducha, łączenie heroizmu z zagadnieniami pamięci zbiorowej, wspólnoty narodowej i ludzkiej, traktowanie heroicznych ideałów jako miary wartości cywilizacyjnych dokonań XIX wieku i dojrzałości człowieka epoki, postrzeganie heroizmu przez pryzmat chrześcijańskich ideałów heroicznych.

\section{Abstract}

The paper contains an interpretation of Norwid's concept of heroism. It refers to a variety of fields in Norwid's literary activity, to his lyric, epic and dramatic works, as well as to his journalistic, critical and epistolary writings. The question of a hero of culture, whose 
significance in the thought and imagination of the author has been presented in the sequence of analyses devoted to leaders of humanity (Prometheus, Moses, the Argonauts, Jesus Christ), national heroes (Krakus, Wanda, heroes of the January Uprising) and poets (the legend of Tyrtheus) is central for the discussion. The above analysis is shown in the context of anthropological reflection of the epoch, the Norwidian concept of an individual, philosophical and religious interpretation of heroic feats, their cultural patterns. The understanding of heroism, as sketched by Norwid against this background, proves to be fully original, though, at the same time, emerging from a multilateral dialogue with the selected threads of heroic tradition. The specificity of Norwid's interpretation of the phenomenon is proved by: underlining the importance of cultural and ethos related meaning of each heroic deed, emphasizing spiritual heroism, associating heroism with the issues of collective memory, the national and human community, treatment of heroic ideals as a measure of value of 19th century civilizational achievements and maturity of the man of that period, given the Christian heroic ideals.

Słowa kluczowe: Cyprian Norwid, heroizm, bohater kulturowy, przewodnik ludzkości, bohater narodowy, poeta

Keywords: Cyprian Norwid, heroism, hero of culture, leader of humanity, national hero, poet

W swej koncepcji człowieka Norwid szczególnie wiele uwagi poświęcał jednostkom wybitnym, co pozwala w nim widzieć nieodrodnego syna swej epoki, żywiącej, jak wiadomo, kult dla wielkich osobistości. Poeta kult ten podzielał, ale zarazem twórczo reinterpretował, nadając mu własną, oryginalną wykładnię. ${ }^{1} \mathrm{~W}$ swej refleksji antropologicznej przekraczał kolejne horyzonty intelektualne swego czasu, przede wszystkim zaś ten wyznaczony przez oświeceniową i romantyczną filozoficzną koncepcję podmiotu i wynikający z niej indywidualizm, w różnych postaciach: od tytanizmu, przez egotyzm, po egoizm i wreszcie antropoteizm. Jak wiadomo, najbliższe było mu personalistyczne myślenie o człowieku². To właśnie w tym kręgu idei poszukiwał istoty ludzkiej wielkości, a zatem postrzegał wybitnego człowieka w kontekście międzyludzkich więzi, życia wspólnotowego: społecznego i narodowego, widział w nim współuczestnika, współtwórcę historii - jednocześnie historii ludzkiej i boskiej historii zbawienia.

Swoiście Norwidowski obszar zainteresowań stanowiła kwestia kulturotwórczej roli osoby ludzkiej, oczywiście zwłaszcza tej naznaczonej wyjątkowością, genialnością, choć uwaga poety niejednokrotnie koncentruje się także na człowieku prostym, zwykłym, szarym, pozornie pozbawionym znaczenia. Rzecz w tym, że

${ }^{1}$ Zob. Z. Szmydtowa, Miara i symbol wielkości w poezji Norwida, Warszawa, Drukarnia W. Łazarskiego, 1930.

${ }^{2}$ Zob. Z. Łapiński, Norwid, Kraków, Wydawnictwo Znak, 1971, ss. 53-99. 
człowiek wybitny to wedle Norwida przede wszystkim ktoś (quidam), kto potrafi wcielić wartości, idee, tendencje właściwe jego macierzystej kulturze, kto potrafi stać się uosobieniem jej niepowtarzalnych cech, ale równocześnie zdolny jest nadać tym cechom sens wykraczający poza dziejowe czy lokalne uwarunkowania ${ }^{3}$. W ten sposób dostarcza osobowego wzoru, staje się przewodnikiem w spluralizowanym świecie kultury. Nie może jednak tego zadania wypełnić, jak sądzi Norwid, bez respektowania normy integralności życia osobowego, a więc ścisłej odpowiedniości myśli i działania, słowa i czynu, prywatnego i publicznego wymiaru istnienia. Życie w prawdzie i dla prawdy staje się zatem niezbywalnym wyznacznikiem ludzkiej wielkości, uniezależniającej się dzięki temu od społecznej pozycji osoby czy od opinii publicznej. A ponieważ prawda domaga się świadectwa, co dla Norwida chrześcijanina jest kwestią oczywista, to $\mathrm{z}$ wielkością powiązane zostają w myśli i wyobraźni pisarza zachowania należące do kanonu aktów heroicznych, a więc szlachetnie odważna postawa moralna, czyli męstwo, manifestowanie mocy ducha wobec uświadomionego i wielkiego niebezpieczeństwa (nawet grożącego śmiercią), zdolność do opanowywania uczuć lęku czy małoduszności, dobrowolna, świadoma gotowość do ofiar, włącznie z oddaniem życia w imię wyższych celów, szczególnie celów społecznych lub religijnych ${ }^{4}$.

Bez wątpienia heroizm to jedno z kluczowych zagadnień Norwidowej refleksji o człowieku, choć - co warte podkreślenia - zagadnienie to nie stało się dotychczas odrębnym problemem badawczym. A przecież Norwid nie ustaje w swych pismach w poszukiwaniu miary heroizmu, analizuje istotę zjawiska, określa jego osobowe wzorce, konfrontuje je ze swą współczesnością, tym samym czyniąc $\mathrm{z}$ heroizmu istotny probierz jej wartości ${ }^{5}$. Ważna okazuje się dla Norwida interpretacja historycznie zmiennych form wyrazu heroizmu, co owocuje ważkimi dialogami intelektualnymi i literackimi czy nawet polemikami, jawnymi bądź prowadzonymi nie wprost. Norwid wykazuje się w ich toku dobrą orientacją w dziedzinie dawnych i nowych teorii cnoty heroicznej, poczynając od Platona i Arystotelesa, przez ideę i świadectwa heroizmu chrześcijańskiego, po prace nowożytnych, a też współczesnych sobie myślicieli podejmujących ten temat, takich jak np. Thomas Carlyle (autor dzieła

${ }^{3}$ Ibidem, ss. 61-62.

${ }^{4}$ Zob. S. Olejnik, Heroizm, [w:] Encyklopedia katolicka, Lublin, Wydawnictwo Towarzystwa Naukowego KUL, 1993, t. VI, szp. 799-800.

${ }^{5}$ Należy odnotować, że również inni twórcy drugiej połowy XIX wieku i początku wieku XX podejmują podobne wysiłki [zob. np. H. Floryńska, Spadkobiercy Króla Ducha, Wrocław, Ossolineum, 1976; M. Micińska, Między Królem Duchem a mieszczaninem. Obraz bohatera narodowego w piśmiennictwie polskim przełomu XIX i XX w. (1890-1914), Wrocław, Wydawnictwo Funna, 1994], jednak obrany przez Norwida kierunek myślenia o heroizmie jest tak dalece unikatowy w swych rezultatach, że trudno o ścisłe analogie. 
Bohaterowie. Cześć dla bohaterów i pierwiastek bohaterstwa w historii), Ralph Waldo Emerson (autor Przewodników ludzkości) czy starszy od nich Giambattista $V{ }^{1} 0^{6}$. Kwestia heroizmu staje się ważkim argumentem w prowadzonej przez Norwida, w trybie wypowiedzi dyskursywnych, a także w praktyce poetyckiej, reinterpretacji form literackich, tradycyjnie uznawanych za ekspresję cnót heroicznych, form takich jak epos czy tragedia. Przykładem tego rodzaju poszukiwań jest zarówno Quidam jak i Pierścień Wielkiej-Damy. Znamienne dla poety jest również dość pryncypialne propagowanie, nauczanie postawy heroicznej, co czyni w przekonaniu o tym, że człowiek jest do heroizmu po prostu wezwany, że niezależnie od momentu historycznego, heroizm jest powinnością istoty ludzkiej, konstytutywnym czynnikiem dojrzałego człowieczeństwa, a przez to również spoiwem życia zbiorowego jako życia wspólnotowego.

Jak widać, i rozległość, i norwidologiczna ranga podnoszonej problematyki pozwalają na wypowiedź skoncentrowaną na kilku zaledwie przykładach, wybranych z szerokiego spectrum interpretacyjnych możliwości. Skupię się zatem na tych Norwidowych oglądach heroizmu, które mogą być postrzegane przez pryzmat kategorii bohatera kulturowego. Pokaźna grupa postaci literackich i pozaliterackich, rozpatrywanych przez pisarza, nosi bowiem cechy, które zarówno w ujęciu etnologicznym jak i kulturowo-socjologicznym zwykliśmy łączyć z tą właśnie kategorią. Gwoli jasności wywodu przypomnę, że termin „bohater kulturowy” odznacza się dużą pojemnością semantyczną - używany jest na określenie postaci mitologicznych, legendarnych, historycznych, a w końcu również wielkich ludzi żyjących współcześnie. Kategorią tą obejmuje się postacie wyróżniające się szczególnymi przymiotami: heroiczną odwagą, ofiarnością, wyjątkowymi zasługami dla ludzkości. W tym gronie znajdują się więc dawcy i nauczyciele kultury, założyciele miast i państw, strażnicy ładu naturalnego, religijnego i prawnego, wielcy władcy, reformatorzy, wynalazcy etc. Ze względu na swe cechy i cywilizacyjne działania bohater kulturowy pełni rolę mediatora - jest usytuowany między światem ludzkim a boskim, sferą profanum a sacrum, a także między jednostką a zbiorowością, uosabia bowiem podstawowe wartości danej społeczności, zaś jego czyny, o znaczeniu paradygmatycznym, mają status kulturowego wzorca?

${ }^{6}$ Jak dowodziła Elżbieta Feliksiak, Norwida łączył z nim między innymi kult Heraklesa jako mitycznego wyobrażenia jednostki twórczej. Zob. E. Feliksiak, Norwid i Vico, [w:] eadem, Poezja i myśl. Studia o Norwidzie, Lublin, Wydawnictwo Towarzystwa Naukowego KUL, 2002, ss. 220-221.

${ }^{7}$ Zob. np. J. Campbell, Hero with a Thousand Faces, New York, Princeton University Press, 1949; H. Tegnaeus, Le héros civilisateur, Stockholm, Studia Ethnographica Upsaliensia, 1950; S. Czarnowski, Kult bohaterów i jego społeczne podłoże. Święty Patryk - bohater narodowy Irlandii, przeł. A. Glinczanka, [w:] idem, Dzieła, t. IV, Warszawa, PWN, 1956; F. Znaniecki, Nauki o kulturze. Narodziny i rozwój, przeł. J. Szacki, Warszawa, PWN, 1971; M. Zowczak, Mit bohaterski jako opowieść 
Uwaga Norwida wielokrotnie koncentruje się na tak rozumianych postaciach, przy czym jest to powiązane zarówno z jego koncepcją ciagłości kultury, niejako immanentnie zobligowanej do pełnej świadomości własnych początków, zdolnej do autentycznego rozwoju jedynie w odniesieniu do źródeł, jak i z hermeneutyką kultury, potrzebą jej permanentnej interpretacji, rewidowania i odnawiania wypracowanych, utrwalonych przez pokolenia znaczeń. Kultura będzie zdaniem Norwida żywa o tyle, o ile zachowa więź ze źródłem, ale i adekwatność w stosunku do współczesności i właściwego jej pola ludzkich doświadczeń. A zatem bohater kulturowy jako wcielenie określonego zespołu wartości, jako wzorzec zachowań podlegać powinien jednoczesnej aktualizacji i interpretacji. Ten znamienny dla Norwida ruch myśli możemy zaobserwować w różnych obszarach jego dzieła, w różnych fazach jego twórczości. Tym bardziej nieunikniona okazuje się konieczność wyboru rozważanych przykładów.

\section{Przewodnicy ludzkości}

W wykreowanym przez poetę obrazie historii uniwersalnej, na której planie usytuowany zostaje człowiek jako aktywny, pełen inwencji twórczej uczestnik procesu dziejowego, zarazem współpracownik Opatrzności, rolę pierwszych przewodników ludzkości pełnią Prometeusz i Mojżesz - reprezentanci dwóch tradycji kultury („Pierwsze dwie tradycje: rozejście - spotkanie”; VII 2428), ucieleśnienia dwóch typów bohatera kulturowego, odmienni, ale i bliscy sobie":

„Stąd M o j z e s, stąd Pro m e te j o dobie tej samej,

Niebieski biorąc ogień dwojakimi bramy,

Skoro jeden szemraniem ludu jest trapiony,

Drugiemu sęp wnętrznoście maca co dzień szpony.

Stąd tam - ówdzie - są m i tó w ciągłe podobieństwa,

Walki też same, cudy, znaki i męczeństwa,

Które, nie wie geograf i chronolog nie wie,

Czemu? jedne a różne, jak liście na drzewie.” (VII 577-578)

o granicach ludzkich możliwości, „Etnografia Polska” 1984, nr 2; D. Penkala-Gawęcka, Bohater kulturowy, [w:] Stownik etnologiczny. Terminy ogólne, pod red. Z. Staszczak, Warszawa, Poznań, PWN, 1987; Ł. Trzciński, Mit bohaterski w perspektywie antropologii filozoficznej i kulturowej, Kraków, Wydawnictwo Uniwersytetu Jagiellońskiego, 2006.

${ }^{8}$ Pisma Norwida cytuję według wydania: C. Norwid, Pisma wszystkie, zebrał, tekst ustalił, wstępem i uwagami krytycznymi opatrzył J.W. Gomulicki, t. I-XI, Warszawa, PIW, 1971-1976. Cyframi rzymskimi oznaczam tom, a arabskimi - strony.

${ }^{9} \mathrm{O}$ obecności tych dwóch tradycji w Norwidowskiej wizji najdawniejszych dziejów ludzkości pisała Elżbieta Feliksiak, odnotowując ślady poszukiwania przez pisarza przeciwieństw i analogii między nimi. Zob. E. Feliksiak, Norwidowski świat myśli, [w:] eadem, Poezja i myśl..., op.cit., ss. 109-115. 
W Promethidionie, w cytowanej powyżej Rzeczyo wolności słowa, w Notatkach $z$ mitologii Norwid przedkłada oryginalną interpretację obu postaci. Jego Prometeusz zachowuje odrębność na tle romantycznych interpretacji postaci tytana. W refleksji Norwida symbolizuje przede wszystkim geniusz twórczy, a jednocześnie osobowość będącą zaprzeczeniem egoizmu, zdolną do cierpienia w imię ogółu, dla dobra ludzkości. To mityczny filantrop, ,,apostoł cywilizacji” (VII 281), pojmowanej jako postęp techniczny i społeczny zarazem. Często pozytywnie waloryzowany przez romantyków prometejski bunt nie znajduje u Norwida bezwarunkowej akceptacji. Prometeusz, jak pisze, „wykrada ogień i zuboża niebiosa” (VII 292), zrywa związek z bóstwem, służy odtąd jedynie człowiekowi, ale jako taki nie odzwierciedla wcale pełni ludzkiej natury.

Z kolei Mojżesz okazuje się w interpretacjach poety nade wszystko współtwórcą prawa i „moralności-zbiorowych-ciał”. Funkcjonuje tu jako strażnik boskich prawd objawionych, symbol etyki społecznej, odpowiedzialności moralnej. Zawierając przymierze z Bogiem („komunia Mojżesza z Bogiem”; VII 288), staje się na wieki pośrednikiem między Nim a człowiekiem:

„Czoła się nam mojżeszą

I zaczynają się lica blaskiem palić.

- Wiatr ogromny, jak na Synai szczycie,

Tętnią echa i gromy z błyskawicami;

Dłonią czujesz, że tknąłeś ż y c i e...

Podejmując Prawa odłamy.” (Moralności, II 79)

Jednak swoiście Norwidowską kreacją przewodnika ludzkości, będącą dopełnieniem obu bohaterów, uwzględniającą też dziewiętnastowieczne samorozumienie artysty, jest Prometej Adam, inkarnacja człowieka wiecznego, który w Promethidionie przekazuje fundamentalne prawdy o pięknu, będącym kształtem miłości, i poucza o znaczeniu pracy:

„Prometej Adam wstał, na rękach z ziemi

Podnosząc się, i mówić zacznie tak: „Próżniacy!

Próżniacy wy - ciekawość siły wam zatrwoży,

Gdy jak o pięknem rzekłem, że jest p r o f i 1 B o ż y

Przez grzech stracony nawet w nas, p r o f i l u c i e n i a c h,

I mało gdzie, i w rzadkich odczuwan sumieniach,

Tak i o pracy powiem, że - z g u b y s z u k a n i e m,

Dla której pieśn - ustawnym jest nawoływaniem”." (III 438-439)

Droga Prometeja Adama wiedzie przez bunt-grzech i pokutę, której ważnym aspektem jest praca, ku pełnemu uczestnictwu w cywilizacyjnym i społecznym roz- 
woju ludzkości. To bohater twórczy, dawca kultury, przez którego działa Opatrzność. Tak więc heroiczny mit prometejski został przez Norwida wszczepiony w tok historii zbawienia, a grecki tytan uzyskał rysy Prometeusza chrześcijańskiego. Norwid nawiązuje tym razem do dwóch głównych wątków mitu o Prometeuszu, które przekazał Ajschylos - wątku buntu w imię autonomii człowieka i wątku pojednania z bóstwem. Zachowując charakterystyczny dla fabuły mitycznej motyw umiejętności i sztuk, pisarz ukazuje je ,nie tylko jako dar usprawniający i uszczęśliwiający życie ludzi na ziemi, lecz również jako zadanie wspomagające - w przymierzu z pracą - drogę człowieka i narodu ku zmartwychwstaniu"10. Prometej Adam to w interpretacji Norwida prototyp chrześcijańskiego artysty, potwierdzającego swą godność i twórczą moc nie w aktach rebelii skierowanej przeciw Bogu, lecz w sztuce-pracy, skojarzonej co prawda z trudem, wyrzeczeniem, cierpieniem, ale i z aktem odkupienia.

W wierszu Bohater (LXXIV ogniwo cyklu Vade-mecum) Norwid przedstawia nieco zmodyfikowany wariant koncepcji przewodników ludzkości. Oczywiście potwierdza przekonanie, że bohaterstwo stanowi trwały czynnik dziejów: „Bohaterowie wszak od wieków w wieki / Kraj zdobywają z a k l ę t y”, uczestnicząc w,D z i e j ó w z a c i ąg u" (II 106). Zarazem poeta wyodrębnia historycznie określone formy heroizmu, będące też jego zróżnicowanymi modelami. Tak więc mit Argonautów reprezentuje w wierszu pierwotną postać heroizmu „czystego” - to mit bohaterski „czasu siły-zupełnéj” (II 105), wcielenie etosu rycerskiego ${ }^{11}$. Następnie Mojżesz łączy czyny bohaterskie z interwencją Boga, przez co uzyskują status cudu. Z kolei chrześcijaństwo rodzi nową odmianę heroizmu - heroizm ducha:

„Miałażby słodycz chrześcijańska, nowa,

Zawistnym być Męstwa druhem? -

Gdy ona raczej, jako białogłowa

Wierna - współ-zwycięża duchem!" (II 106)

${ }^{10}$ S. Sawicki, Wstęp, [w:] C. Norwid, Promethidion. Rzecz w dwóch dialogach z epilogiem, wstęp i oprac. S. Sawicki, Kraków, Wydawnictwo Universitas, 1997, s. 43.

${ }^{11} \mathrm{O}$ wyprawie Jazona jako przedsięwzięciu, do którego zostaje powołane ,rycerstwo najdonośniej słynne" Norwid pisze w Notatkach z mitologii (VII 299). Warto przy okazji dodać, że w odniesieniu do kultury antycznej pisarz używa terminu „heroizm”, przedstawiając w eseju Milczenie (1882) autorską wersję historii myśli greckiej - epoka rozciągająca się pomiędzy twórczością dramatyczną Ajschylosa a dialogami platońskim zyskuje miano heroicznej. Wedle Norwidowskiej periodyzacji przełomową rolę w dziejach filozofii odegrał Diogenes z Synopy, przedstawiciel cynizmu, o którym poeta napisze w Rzeczy o wolności słowa: „C y n i z m w ateńskiej wiedzy panteonie / Był H e r k u 1 e m!” (III 597-598), a tym samym ucieleśnienie ideału filozoficznego nonkonformizmu, krytycyzmu, heroizmu myślenia. Problematykę tę rozwinęłam w artykule: W stronę Diogenesa. Z problemów Norwidowskiej koncepcji kultury, „Wiek XIX. Rocznik Towarzystwa Literackiego imienia Adama Mickiewicza” 2015, ss. 359-378. 
I wreszcie współczesność zostaje przez poetę ironicznie zdiagnozowana jako epoka oddalania się od dawnych ideałów („Nie ma już więcej nic za powołanie / Nad strawność dobrą? byt zdrowy?”; II 106), co jednocześnie budzi niepokój i pytania o ciągłość dziejów, o szanse przetrwania w nowym świecie dawnych wzorców postawy heroicznej. Wiersz zamyka jednak pozbawiona wątpliwości proklamacja nieprzemijającej wartości heroizmu, który jako heroizm pracy może być dla współczesnego człowieka uniwersalnym wyznacznikiem postawy prawdziwie twórczej, nadającej sens jego życiu i śmierci, bo pozwalającej na partycypowanie w dziele boskiego stworzenia: „H e r o i z $m$ będzie trwał, dopóki p r a c a; / Praca? - dopóki stworzenie!..." (II 107).

Norwid, jak widać, podkreśla w swej poetyckiej wizji ciagłości dziejów bohaterstwa znaczenie heroizmu chrześcijańskiego, oczywiście dostrzegając jego swoistość na tle tradycji. Co ważne, pisarz pozostaje w granicach przyjętej przez Kościół wykładni tego zjawiska ${ }^{12}$, a zatem chrześcijański akt heroiczny to dlań więcej niż czyn, w którym przejawia się niezwykłe męstwo, szlachetność, siła i nawet gotowość do poświęcenia się w imię dobra wyższego niż własne życie, co charakteryzowało herosów ery przedchrześcijańskiej, którzy tym samym zasłużyli sobie na pośmiertną sławę. Istotę heroizmu chrześcijańskiego najpełniej odzwierciedla sytuacja męczeństwa, często przywoływana, a nawet przedstawiana w utworach poety, np. w Zwolonie, Dwóch męczeństwach (nawiązanie do męczeństwa św. Pawła), Słodyczy, Czarnych kwiatach (wątek katakumbowy), Quidamie. Chrześcijański męczennik jawi się w nich jako bohater inspirowany przez wiarę, nadzieję oraz miłość Boga i ludzi. Jego heroiczny czyn, spełniany często bez rozgłosu, głęboko przeżywany w cichości ducha, w poczuciu „zwolenia”, czyli współdziałania z łaską i wolą Bożą, okazuje się aktem chrześcijańskiego świadectwa, sposobem najdojrzalszego naśladowania Chrystusa. Nie trzeba dodawać, że wedle Norwida to Jezus Chrystus jest głównym wzorem osobowym ludzkości, aksjologicznym centrum dziejów ${ }^{13}$.

${ }^{12}$ Kwestia heroiczności cnót była przedmiotem namysłu Kościoła w kontekście problematyki kanonizacji i beatyfikacji, co znajduje potwierdzenie w oficjalnych dokumentach, do których należy przede wszystkim De servorum Dei beatificatione et beatorum canonizatione papieża Benedykta XIV. Zob. H. Misztal, Heroiczność cnót, [w:] Encyklopedia katolicka ..., op.cit., t. VI, szp. 798-799; K. Michalski, Heroizm chrześcijański, „Znak” 1948, nr 2, ss. 97-129; K. Michalski, Między heroizmem a bestialstwem, wyd. 3, Kraków, Wydawnictwo Instytutu Teologicznego Księży Misjonarzy, 2010.

${ }^{13} \mathrm{~W}$ chrystocentryzmie badacze upatrują znamiennej cechy Norwidowskiej interpretacji dziejów. Zob. A. Dunajski, Chrześcijańska interpretacja dziejów w pismach Cypriana Norwida, Lublin, Wydawnictwo KUL, 1985, s. 243. 


\section{Bohater narodowy}

Na przełomie lat 40. i 50. krystalizuje się w twórczości Norwida koncepcja bohatera narodowego. Poeta sięga wówczas do przekazów kronikopisarskich, do zawartych w nich legend o początkach polskiej państwowości, przy czym inspirujące okazują się dlań przekazy związane z Krakowem, który, jak wiadomo, Norwid odwiedził w 1842 roku przed swym wyjazdem za granicę. Efektem pogłębionych studiów nad krakowskimi legendami były misteria Krakus oraz Wanda, szczególnie ważne w kontekście poruszanej problematyki ${ }^{14}$.

Czytelnika tych utworów oczywiście nie może zaskakiwać to, że autor z dużą dozą swobody twórczej potraktował narracje kronikarzy. Jednak trzeba zauważyć, że zarazem obrał drogę swoistej interpretacji początków narodowej historii. Rozumiał ją bowiem parabolicznie, jako przedstawienie boskich tajemnic, których odczytanie wymaga aktu przekroczenia powierzchniowej, literalnej warstwy zdarzeń, by poza ich zewnętrznością ujrzeć dzieje święte, odkryć odwieczny plan zbawienia świata. W znacznie później napisanej Filozofii historii polskiej będzie podkreślał, że: „Trzeba [...] tak kształcić swój wzrok, ażebyśmy mogli odgadywać sprawy Boże pod powłoką spraw ziemskich”, gdyż „tajemnica znana kazuistycznie”, a więc jako „,inwentarz faktów”, mogłaby zaspokajać jedynie wówczas: „Gdyby historia [...] nie miała nic Boskiego w całokształcie ustroju swojego (to jest: gdyby właśnie przez to samo ona nie była historią...)" (VII 66).

Obrany przez Norwida tryb interpretacji legendarnej fazy dziejów Polski rzutuje na kreację postaci tytułowych obu misteriów. Ich bohaterowie, ,typy będące jakoby zbiorowości umysłu utwierdzeniem", to reprezentanci nie tylko powszechnych postaw ludzkich, lecz konstrukcje osobowe unaoczniające parabolicznie los i etos społeczności narodowej, sytuowanej wobec boskiej transcendencji, na planie dziejów zbawienia. Tym samym Norwidowski bohater narodowy przynależy równocześnie do obu porządków historii. W przypadku Wandy autor dąży nawet do ich ścisłego zsynchronizowania - sugeruje, że śmierć bohaterki następuje w tym samym czasie, co śmierć Chrystusa na Golgocie. Z kolei Krakusowe zmagania ze smokiem opanowującym gród Kraka znajdują wykładnię w kontekście walki ze złem, toczonej

${ }^{14} \mathrm{O}$ utworach tych jako dramatach misteryjnych pisałam w książce: ,, Misteria polskie”. Z problemów misteryjności w dramacie romantycznym i modernistycznym, Kraków, Wydawnictwo Universitas, 1996, ss. 48-68. W niniejszym artykule nawiązuję do niektórych sformułowanych w niej tez. Zob. również: Z. Szmydtowa, O misteriach Cypriana Norwida, Warszawa, Wydawnictwo Kasy im. Mianowskiego, 1932; J. Maślanka, „Krakus” Norwida-misterium narodowe, „Ruch Literacki” 1983, nr 6, ss. 453-468; W. Szturc, Mit fundacyjny narodu w ,,Wandzie” Cypriana K. Norwida, [w:] idem, O obrotach sfer romantycznych, Bydgoszcz, Wydawnictwo Homini, 1997, ss. 127-137. 
w obrębie dziejów upadku człowieka i odkupienia, gdyż krajowi zagraża „smok odwylęgany”, „odrośl kaleki” tego, któremu „Dziewicy nogą w ziemi dalekiej / [...] głowę starto pierwotną" (VI 170).

W centrum akcji obu utworów Norwid umieszcza wątek walki bohatera ze złem, co pozostaje w zgodzie z dobrze znanym wariantem losów bohatera kulturowego. Konfrontacja ze złem to sytuacja prowokująca do otwartej walki, do zbrojnego czynu, do zachowań heroicznych. Krakus obiera jednak zupełnie inną strategię działania - nie opowiada się po stronie heroizmu miecza, świadomie i dobrowolnie wybiera heroizm ducha. Czyn, który polega na zabiciu smoka, zostaje poprzedzony w dramacie rozbudowaną sekwencją zdarzeń, mających status akcji wewnętrznej, obrazujących przebieg indywidualnego wtajemniczenia bohatera w duchowe tajniki świata. Ponieważ smok nie jest jedynie obiektywnie istniejącym bytem, który zagraża z zewnątrz, lecz również „pożercą dusz”, to jego pokonanie nie wydaje się możliwe bez aktu samopoznania, samoprzezwyciężenia, duchowej walki pozwalającej uznać pozorność nicestwiącej działalności zła wobec mocy istnienia. Po spotkaniu z Progiem ruiny zamku bohater misterium spoczywa w grocie szmaragdowej. Pogrążony we śnie, który jest tu zarazem metaforą śmierci, uczestniczy w akcie kultowym, noszącym wszelkie znamiona liturgii eucharystycznej - spożywa posiłek ofiarny jak eucharystyczne ciało, pije źródlaną wodę jak eucharystyczne wino, a wszystko to dokonuje się w przestrzeni groty, która ozdobiona szmaragdami przywołuje wyobrażenie wnętrza kielicha Graala. Ta liturgiczna akcja uobecnia moment Ostatniej Wieczerzy, a poprzez nią wprowadza w misterium paschalne, objawia tajemnice śmierci i zmartwychwstania, stanowi też zapowiedź Uczty Mesjańskiej, antycypuje zatem ostateczną, eschatologiczną przemianę. Można więc powiedzieć, że rolę mistrza inicjacyjnego pełni wobec Krakusa sam Chrystus, figuralnie przedstawiony jako Próg i źródło wody życia, uobecniony za pośrednictwem liturgicznych znaków. W rezultacie Krakus doświadczy poczucia absolutnej harmonii między wolą ludzką a boską i stanie do walki ze smokiem jako ,nowy człowiek” - pokorny, cierpliwy, anonimowy, ukryty pod mnisią szata, z harfą w ręku i śpiewem na ustach. W ramach historii ludzkiej bohater poniesie klęskę - pogromca zła zostanie ostatecznie zabity przez własnego brata w rywalizacji o władzę, ale w ramach historii zbawienia jego ofiarny czyn okaże się owocny - historia Polski, ład narodowy zostaną włączone w tok historii świętej.

Analogiczne doświadczenie inicjacyjne obserwować możemy w Wandzie. Nie zostało ono jednak udramatyzowane i przedstawione w symbolicznie ukształtowanej scenie, jak ma to miejsce w Krakusie, lecz zrelacjonowane przez tytułową bohaterkę. Akcja dramatu odzwierciedla proces dojrzewania Wandy do osiagnięcia stanu wtajemniczenia. Zrazu nęka ją poczucie braku, osamotnienia, zagrożenia przez ciemności, które „na świat lecą niespożyte”. Dlatego pragnie zmiany, odrodzenia, 
„nowej szaty”. Przygotowana, dzięki postawie duchowego skupienia i kontemplacji ciszy, w końcu rozpoznaje swe właściwe powołanie i gotowa jest podjąć ofiarę na wzór ofiary Chrystusa, aby ocalić swój lud przed złem, którego wcieleniem są germańskie wojska, a którego oddziaływanie władczyni odkrywa także w sobie, pod wpływem namów Rytygiera i rodzącego się doń uczucia. W ostatniej scenie dramatu Wanda przewalcza napór ciemności, wstępuje na stos, spełnia czyn-ofiarę. W warstwie obrazowej dramatu wyraża to opis składanego w ofierze ciała królowej, które „W Wisłę przelało się”, połączyło się z jej nurtem na znak, że idea Chrystusowej ofiary przeniknęła polską ziemię i nadała nowe znaczenie dziejom zamieszkującego ją narodu. O źródłach i duchowym sensie swego działania bohaterka mówi w ten sposób:

„Dobrzy ludzie!... widziałam cień ogromny Boga,

Przechodzący po polach jak szeroka droga,

A to był tylko ręki jednej cień - ta ręka

Jakby przebitą była, bo słońce padało

Przez wnętrze dłoni, na wskroś, jak przez wypaść sęka.

Ja stałam - i patrzyłam w to rozdarte ciało,

Jak ptak z ciemności w jasną pogląda szczelinę,

I dano mi jest widzieć - to...

... że dla was zginę..." (IV 155-156)

I Krakus, i Wanda spełniają akt heroiczny jako akt ofiary z własnego życia, a czynią to w geście naśladowania Chrystusa. Zarazem jest to akt fundacyjny narodu skupionego wokół Chrystusowych wartości. W osobach swych bohaterów naród otrzymuje wzór postępowania - zwłaszcza w sytuacji kryzysu, zagrożenia złem. Znamienne, że Norwid kładzie nacisk na znaczenie wysiłku wewnętrznego, jednoznacznie afirmuje duchowy aspekt heroizmu. Co więcej, bohater narodowy i jego czyny są przezeń traktowane jako treść ducha narodu, kanwa zbiorowej więzi i zbiorowej pamięci, o czym przekonuje kończąca dramat scena usypywania Krakusowi kopca, mogilny kurhan staje się bowiem znakiem „moralnej-całości-narodu”, ciągłości narodowej historii, dziedzictwa, które, przekazywane z pokolenia na pokolenie, jednoczy we wspólnocie żywych i umarłych.

Ambiwalentny stosunek Norwida do heroizmu miecza potwierdza ze szczególną mocą jego twórczość z okresu powstania styczniowego (wiersze, listy, memoriały, przemówienia, notatki). Jak niejednokrotnie zauważano ${ }^{15}$, pisarz zachowuje wobec

${ }^{15}$ Zob. T. Makowiecki, Norwid wobec powstania styczniowego, „Pamiętnik Literacki” 1929, z. 4, ss. 564-581; Norwid wobec powstania styczniowego, red. P. Chlebowski, Lublin, Wydawnictwo KUL, 2017. 
insurekcyjnych wypadków szacunek i żarliwą nadzieję, ale nie stroni też od ujawniania obaw, gdyż interpretuje powstanie zarazem w kategoriach walki duchowej. Bój z Rosją jest „przede wszystkim O TO TYLKO, tj. O DUCHA” - napisze w 1863 roku (List do K. Ruprechta, 1 IX 1863; IX 105). Zagrożeniem dla ducha narodowego mogą okazać się, jak sądzi, czyny na zewnątrz bohaterskie, a nawet męczeńskie, ale w głębi naznaczone niecierpliwością, niedojrzałością, pochopne, straceńcze. Szafowanie ludzką krwią łatwo bowiem może doprowadzić do stanu ,jednostronności heroicznej” czy wręcz „upadku heroicznego” (Noty o konieczności presji moralnej; VII 131, 133). Z pewnością nie tędy wedle Norwida wiedzie droga ku przyszłości ${ }^{16}$, ku celom uwzględniającym ideał organicznego rozwoju wspólnoty narodowej.

\section{Wokół heroizmu poety}

W latach 60. Norwid po raz kolejny w swej twórczości stawia pytania o kondycję poety, o miejsce i cele poezji w życiu zbiorowym, wyraźnie akcentując wówczas kwestię powołania poety do heroizmu. W wygłoszonych w roku 1860, a opublikowanych rok później Wykładach o Juliuszu Stowackim, przedstawia w I prelekcji historię poezji, wyraziście unaoczniając wyjątkowość stanowiska poety w społeczności ${ }^{17}$. Wykład traktuje o przypisanej mu misji kreowania sfery publicznej, o jego „socjalnej godności” (VI 409), wynikającej przede wszystkim z faktu, że i życie zbiorowe, i sztuka czerpią ze wspólnego sakralnego źródła. Ów nierozerwalny związek poezji z funkcjonowaniem społeczeństw Norwid dostrzega zarówno w historii Izraela, w działaniu proroków, których „urząd i godność” odpowiadały temu, co „dziś nazywamy sędzią przysięgłym” (VI 408), jak i w historii starożytnej Grecji, gdzie ,poeta o r f e i c z n y wielce do proroka izraelskiego podobny; dra m a t y c z n y - to kapłan, albowiem ołtarz jest przed scena, b o h a t e r s k i zaś - to znów historyk albo muzyki wojennej przewódzca" (VI 408). Dopiero w Rzymie ta fundamentalna więź zostaje przerwana: „poeci przechodzą już na stanowisko wyłącznie literackie" (VI 409), koncentrują się na zagadnieniach przede wszystkim estetycznych. Wraz z tym, jak „Sybille zaczynają przestawać mówić”, „prawdziwi poeci milkna, albo są to już pedagogowie, nauczyciele i klienci, co bez mecenasów się obejść nie mogą, z powodu, że ich stanowisko społeczne jest wątpliwe" (VI 409).

${ }^{16}$ „Przyszłość albowiem zdobywają te trzy rzeczy: d u c h, c i e r p li w o ść i d o p e łni e n i e - a le w c a le n i e k r e w: to b a j k a"-pisał w liście do Karola Ruprechta 21 IX 1863 roku (XI 111).

${ }^{17}$ Ten aspekt Wykładów o Juliuszu Stowackim analizowałam w artykule: Cypriana Norwida sztuka żywego słowa, „Ruch Literacki” 2017, nr 4, ss. 359-376. 
Ten regres społecznego znaczenia poety i poezji zostaje jednak wedle Norwida zahamowany - wraz z aktem Wcielenia Słowa. Chrześcijaństwo radykalnie zmienia pozycję socjalną poety, ponownie stawia go w centrum życia społecznego, powierza mu urząd kapłana nadziei, kierowanej już nie ku indywiduom (tę misję wypełnił Chrystus), lecz ku zbiorowościom. Chrześcijański poeta to zatem profeta, organizator świata wartości i wyobraźni zbiorowej, przywódca chrześcijańskiego postępu, przewodnik w drodze ku chrześcijańskiej cywilizacji, ku Ojczyźnie, ku „z i e m i obi e c a nej” i „s p oł e c zn oś c i o b i e c a n e j” (VI 412). To ktoś, kto, naśladując Chrystusa, nieustannie toczy swym słowem walkę o nadzieję powszechną, która wydaje się Norwidowi niezwykle krucha i zewsząd zagrożona ${ }^{18}$.

Jak wiemy, Norwid jest po chrześcijańsku przekonany, że nie wystarczy samo poznanie prawdy, trzeba nią żyć, trzeba nieustannie dawać jej świadectwo. Jak zatem może ten wymóg spełnić poeta? Oczywiście mając za źródło i wzór Słowo Wcielone, czyli tworząc poezję, w której zachowana byłaby zasada tożsamości słowa i życia, słowa i prawdy, słowa i czynu. W dziewiętnastym stuleciu ideał ten realizuje Byron, o którym Norwid powie, jakże znacząco parafrazując ewangeliczną frazę: Ecce poeta! (VI 415). Ale Byron ma, według prelegenta, kontynuatorów w całej Europie, bowiem nastał czas, gdy ,postawiono $1 \mathrm{u} \mathrm{d} \mathrm{z} \mathrm{i} \mathrm{s} \mathrm{ło} \mathrm{w} \mathrm{a} \mathrm{na} \mathrm{czele} \mathrm{rzeczy}$ dziejących się" (VI 424). Poeci powstania listopadowego, O’Connell, Lamartine, Mickiewicz, Kossuth, tak jak Byron, „z Homera lirą i Leonidasa mieczem” (VI 422), łączą poezję i działanie, etos twórczy i etos żołnierski, heroizm ducha i heroizm miecza.

W ścisłym związku z zarysowanym powyżej kręgiem zainteresowań Norwida pozostaje osoba Tyrteusza, który wkracza do świata myśli i wyobraźni poety właśnie w latach 60., a czego najlepszym dowodem, poza próbami tłumaczenia jego poezji, jest tragedia Tyrtej, powiązana w dyptyk dramatyczny z utworem Za kulisami ${ }^{19}$. Jak pamiętamy, legenda uczyniła Tyrteusza patronem poezji nawołującej do boju, wzorem poety zaangażowanego w życie publiczne, duchowego przywódcy narodu, łączącego słowo poetyckie i czyn o znaczeniu historycznym, przekraczającego granicę między literaturą a rzeczywistością społeczną. Świadczyć o tym miała zarówno postawa Tyrtajosa, wodza prowadzącego Spartan do zwycięstwa w drugiej wojnie

18 „Nadzieja, mimo zwycięstwa na Golgocie, odnadzieja się nieraz na powrót, to zwycięstwo albowiem bynajmniej nas od prac i obowiązków nie uwolniło, skąd jest też wiele do walczenia we dnie powszednie nadziei, chociażby dlatego tylko, że z pogaństwem się ciagle spotykamy, bo znów przez dziewiętnaście wieków nagromadzały się i nagromadziły żywioły barbarzyństwa” (VI 418).

${ }^{19} \mathrm{O}$ relacjach zachodzących między obydwoma tekstami traktuje studium: I. Sławińska, T. Makowiecki, Za kulisami , Tyrteja”, [w:] O Norwidzie pięć studiów, Toruń, Księgarnia Naukowa T. Szczęsny i S-ka, 1949, ss. 33-64. 
messeńskiej, jak i tworzona przezeń poezja, w większości elegie ekshortacyjno-militarne, w których twórca wzywa do dzielności i przyjęcia aktywnej, nieugiętej postawy w działaniach wojennych. Jednocześnie, korzystając z formuł Homera, polemizuje z epicką koncepcją cnoty. Ideałowi jednostkowej sławy, zaszczepianemu w kulturze arystokratycznej, przeciwstawia ideał spartańskiej wspólnoty. Prawdziwa cnota polega, zdaniem Tyrtajosa, na odwadze i walorach bojowych żołnierza walczącego w obronie swej ojczyzny. Heroizm znajduje tu uzasadnienie w patriotyzmie ${ }^{20}$.

W Tyrteju Norwid dokonuje głębokiej rewizji legendy greckiego poety-wodza, a zarazem reinterpretuje jakże znaczący temat romantycznej poezji, którego kolejne nasilenie w literaturze polskiej można było obserwować w związku z wybuchem powstania styczniowego. W poezji tej doby pojawiają się tak liczne odwołania do postaci Tyrteusza (m.in. Mieczysław Romanowski, Władysław Anczyc, Kornel Ujejski, Teofil Lenartowicz, Felicjan Faleński) ${ }^{21}$, że można mówić o kontynuacji romantycznego nurtu poezji tyrtejskiej. Jednak wbrew tradycji, także rodzimej, Tyrteusz przedstawiony jest w Norwidowskim dramacie jako poeta mało znany i niezbyt ceniony. Dla Ateńczyków stanowi on przedmiot pośmiewiska, nie tylko ze względu na poetyckie ambicje, ale również jako kaleka. W ślad za przekazami historycznymi autor czyni bohatera człowiekiem chromym i niedowidzącym. Tym samym Tyrteusz został przez Norwida wykreowany na poetę nieakceptowanego, nierozumianego, wyalienowanego z ówczesnego życia społecznego, w czym nietrudno się doszukać przejawów autokreacji, uwspółcześniającej portret antycznego twórcy. Sytuacja bohatera dramatu, jego społeczna pozycja ulega zmianie dopiero na skutek decyzji wyroczni delfickiej powierzającej mu funkcję wodza Spartan, jednak sam Tyrtej nie żywi wattpliwości co do szczerości intencji ludzi okazujących mu wówczas szacunek.

Stosunek Norwidowego Tyrteja do powierzonej mu misji również nie odpowiada wersji legendowej. Przede wszystkim bohater ma pełną świadomość obumarcia kultury spartańskiej. Jego ustami Norwid dokonuje rewizji romantycznego wyobrażenia Sparty mężnej, zdolnej do twórczego działania, do aktów poświęcenia za ojczyznę: „Lud ten cały z $\mathrm{z}$ ż e 1 e ź n i a ł ... [...] Już skończyło się wszystko, i bóg tam nic ni e two r z y w i ę c e j... [...] I posłany jestem... ja, nim dla Bogów ojca miejsce się znajdzie..." (IV 497). Swą misję pojmuje zatem Tyrteusz jako nakaz

${ }^{20}$ Zob. np. Literatura Grecji starożytnej, pod red. H. Podbielskiego, Lublin, Wydawnictwo Towarzystwa Naukowego KUL, 2005, t. I, ss. 329-333; Liryka starożytnej Grecji, oprac. J. Danielewicz, Warszawa, Poznań, PWN, 2001, ss. 99-101.

${ }^{21}$ Zob. Z. Trojanowiczowa, Tyrteizm, [w:] Słownik literatury polskiej XIX wieku, red. J. Bachórz, A. Kowalczykowa, Wrocław, Zakład Narodowy Imienia Ossolińskich - Wydawnictwo, 1991, ss. 973976. 
poprowadzenia Spartan nie ku zwycięstwu - tak nakazywałaby legenda - lecz ku klęsce w walce z powstańcami messeńskimi. Udaje się do Sparty, aby „ułatwić historyczny skon jej obecnego ustroju i obecnej kultury, który umożliwi powstanie nowej formacji człowieka"22. Tyrtej Norwida potrafi bowiem w swym działaniu wznieść się ponad bieżącą chwilę, ogarnia myślą długie trwanie kultury, paradoksalnie, przez klęskę pragnie odnieść zwycięstwo dla przyszłości, a ściślej: dla chrześcijańskiej przyszłości. Swą misję traktuje jako akt nie militarny, lecz należący do duchowych dziejów ludzkości, a porównywalny z postępowaniem ostatniego króla Aten, Kodrusa, który ponosząc śmierć od dzid doryjskich „kamieniem stał się węgielnym przeobrażenia ludu, i oto głęboka Aten żałoba rozrzewniła się po nim w republikę. Nie nauczał on służby warsztatu jak rzemieślnik tępy i surowy, ale gestem jednym jako mistrz tworzył na wieki!” (IV 498). Gest Kodrusa, uznany za „współboski”, za rodzaj ofiary, stanowi dla Tyrteja wzór i źródło samorozumienia. Zachowanie to zyskuje na znaczeniu również w kontekście motywiki chrześcijańskiej, dyskretnie w dramacie zarysowanej, ale semantycznie ważkiej.

Przypisana wydaje się Tyrteuszowi Norwida idea poezji-czynu, poezji traktowanej jako bojowa pobudka, jako narzędzie walki o wolność, choć zarazem jest on daleki od utożsamienia wolności z wolnością jedynie polityczną. Sprawczą siłę poezji łączy nie $\mathrm{z}$ agitacją patriotyczna, lecz z przekonaniem o duchowej mocy poetyckiego słowa w stosunku do życia pojedynczych ludzi i całych społeczności, poezja zdolna jest je bowiem twórczo przeobrażać. Dlatego w monologu protagonisty dramatu, będącym wyrazem jego koncepcji poezji, jako wzorzec artysty pojawi się zstępujący do Hadesu Orfeusz, w profetycznej wizji Tyrteja sprzężony w jeden ciagg obrazów ze zstępującym do piekieł królem-poddanym, czyli Chrystusem ${ }^{23}$. Z tego fragmentu utworu wyłania się myśl o poezji jako sile niosącej światło kultury, poczucie harmonii (odpowiada za te dziedziny Orfeusz, w ten sposób interpretowany przez Norwida również w innych utworach), a nade wszystko wybawiającej od śmierci, niosącej zmartwychwstanie. Można powiedzieć, że jest to ideał piastowany przez Tyrteusza na przekór rzeczywistości. Wszystko wokół skłania go przecież do zwątpienia w wysoką rangę poezji i poety.

Tak głęboko zinterpretowana legenda Tyrteusza i idea poezji tyrtejskiej są przez Norwida konfrontowane $\mathrm{z}$ realiami dziewiętnastowiecznego życia społecznego. Wewnątrztekstowym autorem tragedii Tyrtej jest bowiem współczesny poeta Omegitt, bohater drugiej części dyptyku Za kulisami. W tej partii dzieła Norwid

${ }^{22}$ S. Sawicki, Tyrteusz Wielki Norwida, [w:] idem, Norwida walka z forma, Warszawa, PIW, 1986, s. 127.

${ }^{23}$ Zob. A. Ziołowicz, Dramat i romantyczne Ja. Studium podmiotowości w dramaturgii polskiej doby romantyzmu, Kraków, Wydawnictwo Universitas, 2002, ss. 291-314. 
przedstawia jego artystyczną klęskę - tragedia o Tyrteju zostaje wygwizdana, a wraz z nią publiczność odrzuca określone wartości. Norwid podaje tym samym w wątpliwość żywotność wzorca heroizmu ucieleśnianego przez greckiego poetę. Omegitt wydaje się ostatnim wyznawca, interpretatorem, obrońcą tego ideału. Wskazywałoby na to znaczące imię bohatera, które sugeruje, że mamy do czynienia z człowiekiem usytuowanym gdzieś u kresu czasu, z człowiekiem przechodzącym przez graniczne doświadczenie egzystencjalne, unaocznione tu jako zstąpienie do piekła dziewiętnastowiecznej „bękarciej cywilizacji”. W dramacie Za kulisami Norwid tworzy wielką metaforę swej współczesności - świata oderwanego od prawdy, świata, który przestał być jej świadectwem. Fantasmagoryjna maskarada rozgrywająca się za kulisami sceny, na której grany jest Tyrtej, uzmysławia stopień spustoszeń w ludzkim życiu ukazuje utratę ontycznej podstawy istnienia, dezintegrację wspólnoty narodowej, triumf fałszu w relacjach międzyludzkich, zanik społecznego i metafizycznego sensu sztuki. W tej rzeczywistości ani dawne heroiczne ideały, ani odnowione przez Omegitta-dramaturga rozumienie heroizmu, nie mogą znaleźć posłuchu.

Norwid (podobnie jak Omegitt) będzie poszukiwał nowej formuły heroizmu, wielokrotnie poruszając kwestię adaptowania dawnego dyskursu heroicznego do dziewiętnastowiecznych doświadczeń człowieka i właściwych mu form ekspresji. Zwłaszcza w swej liryce podejmie się interpretowania i upamiętniania ważkich, acz współczesnych sobie przejawów postawy heroicznej. Józef Bem (Bema pamięci żatobny-rapsod), Fryderyk Chopin (Fortepian Szopena), Adam Mickiewicz (Duch Adama $i$ skandal), gen. Henryk Dembiński (Na portret generała Dembińskiego), Jan Gajewski (Na zgon śp. Jana Gajewskiego), duchowni z Tunki (,, Ołówkiem” na ksiażeczce o Tunce), John Brown (Do obywatela Johna Brown, John Brown), emir Abd el-Kader (Do emira Abd el Kadera w Damaszku) - to bohaterowie XIX stulecia, widziani przez pryzmat idei heroiczności cnót, sytuowani przez poetę w kontekście różnych tradycji i modeli heroizmu. Norwid nie wątpi w wyjątkową wartość ich życia i dokonań, ale w wierszu Coś Ty Atenom zrobit, Sokratesie dobitnie unaocznia, jak wielkim problemem może być społeczna akceptacja autentycznej wielkości człowieka, jego heroicznej roli w kulturze, a tym samym jak utrudnione jest wzorcotwórcze oddziaływanie bohaterów, zwłaszcza w czasie cywilizacyjnego kryzysu, którym dotknięty jest wiek XIX.

Na zakończenie - kilka słów podsumowania. Warianty bohatera kulturowego i związane z nimi heroiczne ideały podlegają przeobrażeniom w twórczości Norwida wraz z upływającym czasem i przesunięciami w obrębie intelektualnych i aksjologicznych priorytetów twórcy. Sądzę, że można jednak, oczywiście za cenę pewnych uproszczeń, wyszczególnić zespół stałych wyznaczników Norwidowskiego rozumienia heroizmu. Po pierwsze, charakterystyczny dla Norwida jest ogląd aktu heroicznego jako aktu o znaczeniu kulturowym; kultura rodzi się dzięki heroicznym 
postawom; autentycznie kulturotwórcza działalność ma aspekt heroiczny; w tych kategoriach pisarz postrzega także własne działania. Po drugie, Norwid bardzo silnie eksponuje znaczenie heroizmu ducha, zachowując ambiwalentny stosunek do heroizmu miecza w przekonaniu, że celem ludzkości jest jego wyeliminowanie, „,uniepotrzebnienie" związanego z nim męczeństwa - przez ,wcielanie dobra i rozjaśnianie prawd" (III 466). Po trzecie, poetę interesuje heroizm w kontekście zagadnień pamięci zbiorowej, wspólnoty narodowej i ludzkiej, dla których może być fundamentem i spoiwem istnienia jako źródło wysokich wartości, jako etosowy wzorzec. Po czwarte, heroiczne ideały stanowią miarę wartości dla cywilizacyjnych dokonań XIX stulecia; heroizm staje się zatem w rozumowaniu poety ważkim argumentem w prowadzonej przezeń krytyce współczesności, nie skłonnej - jak sądzi - do jednoznacznego afirmowania postawy heroicznej, a także istotnym punktem odniesienia w naznaczonej pesymizmem refleksji antropologicznej - heroizm jako miara dojrzałości osoby i pełni ludzkiego życia obnaża wszelkie słabości człowieka XIX wieku. Po piąte, Norwid nieodmiennie postrzega heroizm przez pryzmat chrześcijańskich ideałów heroicznych, tzn. przez pryzmat ofiary, świadectwa dawanego Prawdzie, powinności naśladowania Chrystusa; traktuje kultywowanie tak rozumianego heroizmu jako drogę do zbawienia.

\section{Literatura}

Campbell J., Hero with a Thousand Faces, New York, Princeton University Press, 1949, 416 ss.

Czarnowski S., Kult bohaterów i jego społeczne podłoże. Święty Patryk-bohater narodowy Irlandii, przeł. A. Glinczanka, [w:] idem, Dzieła, t. IV, Warszawa, PWN, 1956, 255 ss.

Dunajski A., Chrześcijańska interpretacja dziejów w pismach Cypriana Norwida, Lublin, Wydawnictwo KUL, 1985, 282 ss.

Feliksiak E., Norwid i Vico, [w:] eadem, Poezja i myśl. Studia o Norwidzie, Lublin, Wydawnictwo Towarzystwa Naukowego KUL, 2002, ss. 213-248.

Feliksiak E., Norwidowski świat myśli, [w:] eadem, Poezja i myśl. Studia o Norwidzie,

Lublin, Wydawnictwo Towarzystwa Naukowego KUL, 2002, ss. 87-170.

Literatura Grecji starożytnej, pod red. H. Podbielskiego, t. I, Lublin, Wydawnictwo Towarzystwa Naukowego KUL, 2005, ss. 329-333.

Łapiński Z., Norwid, Kraków, Wydawnictwo Znak, 1971, ss. 53-99.

Makowiecki T., Norwid wobec powstania styczniowego, „Pamiętnik Literacki” 1929, z. 4, ss. 564-581. 
Maślanka J., „,Krakus” Norwida - misterium narodowe, „Ruch Literacki” 1983, nr 6, ss. 453-468.

Michalski K., Heroizm chrześcijański, „Znak” 1948, nr 2, ss. 97-129.

Michalski K., Między heroizmem a bestialstwem, wyd. 3, Kraków, Wydawnictwo Instytutu Teologicznego Księży Misjonarzy, 2010, 349 ss.

Misztal H., Heroiczność cnót, [w:] Encyklopedia katolicka, Lublin, Wydawnictwo Towarzystwa Naukowego KUL, 1993, t. VI, szp. 798-799.

Norwid wobec powstania styczniowego, red. P. Chlebowski, Lublin, Wydawnictwo KUL, 2017, 261 ss.

Olejnik S., Heroizm, [w:] Encyklopediakatolicka, Lublin, Wydawnictwo Towarzystwa Naukowego KUL, 1993, t. VI, szp. 799-800.

Penkala-Gawęcka D., Bohater kulturowy, [w:] Słownik etnologiczny. Terminy ogólne, pod red. Z. Staszczak, Warszawa, Poznań, PWN, 1987, ss. 53-55.

Sawicki S., Tyrteusz Wielki Norwida, [w:] idem, Norwida walka z forma, Warszawa, PIW, 1986, ss. 121-134.

Sawicki S., Wstęp, [w:] C. Norwid, Promethidion. Rzecz w dwóch dialogach z epilogiem, wstęp i oprac. S. Sawicki, Kraków, Wydawnictwo Universitas, 1997, ss. 5-49.

Sławińska I., Makowiecki T., Za kulisami ,, Tyrteja”, [w:] O Norwidzie pięć studiów, Toruń, Księgarnia Naukowa T. Szczęsny i S-ka, 1949, ss. 33-64.

Szmydtowa Z., Miara i symbol wielkości w poezji Norwida, Warszawa, Drukarnia W. Łazarskiego, 1930, 20 ss.

Szmydtowa Z., O misteriach Cypriana Norwida, Warszawa, Wydawnictwo Kasy im. Mianowskiego, 1932, 194 ss.

Szturc W., Mit fundacyjny narodu w ,Wandzie” Cypriana K. Norwida, [w:] idem, O obrotach sfer romantycznych, Bydgoszcz, Wydawnictwo Homini, 1997, ss. 127-137.

Tegnaeus H., Le héros civilisateur, Stockholm, Studia Ethnographica Upsaliensia, 1950,224 ss.

Trojanowiczowa Z., Tyrteizm, [w:] Słownik literatury polskiej XIX wieku, red. J. Bachórz, A. Kowalczykowa, Wrocław, Zakład Narodowy Imienia Ossolińskich Wydawnictwo, 1991, ss. 973-976.

Trzciński Ł., Mit bohaterski w perspektywie antropologii filozoficznej i kulturowej, Kraków, Wydawnictwo Uniwersytetu Jagiellońskiego, 2006, 211 ss.

Ziołowicz A., Dramat i romantyczne Ja. Studium podmiotowości $w$ dramaturgii polskiej doby romantyzmu, Kraków, Wydawnictwo Universitas, 2002, ss. 291-314.

Ziołowicz A., „Misteria polskie”. Z problemów misteryjności $w$ dramacie romantycznym i modernistycznym, Kraków, Wydawnictwo Universitas, 1996, ss. 48-68. 
Ziołowicz A., W stronę Diogenesa. Z problemów Norwidowskiej koncepcji kultury, „Wiek XIX. Rocznik Towarzystwa Literackiego imienia Adama Mickiewicza” 2015, ss. 359-378.

Ziołowicz A., Cypriana Norwida sztuka żywego słowa, „Ruch Literacki” 2017, nr 4, ss. 359-376.

Znaniecki F., Nauki o kulturze. Narodziny i rozwój, przeł. J. Szacki, Warszawa, PWN, 1971, 427 ss.

Zowczak M., Mit bohaterski jako opowieść o granicach ludzkich możliwości, „Etnografia Polska” 1984, nr 2, ss. 243-267.

\section{References}

Campbell J., Hero with a Thousand Faces, New York, Princeton University Press, 1949, 416 pp.

Chlebowski P. (Ed.), Norwid wobec powstania styczniowego [Norwid's Attitude towards the January Uprising], Lublin, Wydawnictwo KUL, 2017, 261 pp.

Czarnowski S., Kult bohaterów i jego społeczne podtoże. Święty Patryk - bohater narodowy Irlandii [The Hero Cult and its Social Background. St. Patrick - the Irish National Hero], trans. A. Glinczanka, [in:] idem, Dzieła [Works], vol. IV, Warszawa, PWN, 1956, 255 pp.

Dunajski A., Chrześcijańska interpretacja dziejów wpismach Cypriana Norwida [The Christian Interpretation of History in Norwid's Writing], Lublin, Wydawnictwo KUL, 1985, 282 pp.

Feliksiak E., Norwid i Vico [Norwid and Vico], [in:] eadem, Poezja i myśl. Studia $o$ Norwidzie [Poetry and Thought. Studies on Norwid], Lublin, Wydawnictwo Towarzystwa Naukowego KUL, 2002, pp. 213-248.

Feliksiak E., Norwidowski świat myśli [Norwid's World of Thought], [in:] eadem, Poezja i myśl. Studia o Norwidzie [Poetry and Thought. Studies on Norwid], Lublin, Wydawnictwo Towarzystwa Naukowego KUL, 2002, pp. 87-170.

Łapiński Z., Norwid [Norwid], Kraków, Wydawnictwo Znak, 1971, pp. 53-99.

Makowiecki T., Norwid wobec powstania styczniowego [Norwid's Attitude towards the January Uprising], „Pamiętnik Literacki” [Literary Diary] 1929, no. 4, pp. 564-581.

Maślanka J., „,Krakus” Norwida - misterium narodowe [Norwid's "Krakus” - a National Mysterium], „Ruch Literacki” [Literary Movement] 1983, no. 6, pp. 453468.

Michalski K., Heroizm chrześcijański [The Christian Heroism], „Znak” [Sign] 1948, no. 2 , pp. 97-129. 
Michalski K., Między heroizmem a bestialstwem [Between the Heroism and the Beastliness], 3nd ed., Kraków, Wydawnictwo Instytutu Teologicznego Księży Misjonarzy, 2010, pp. 349.

Misztal H., Heroiczność cnót [Heroic Virtues], [in:] Encyklopedia katolicka [Catholic Encyclopedia], Lublin, Wydawnictwo Towarzystwa Naukowego KUL, 1993, vol. VI, pp. 798-799.

Olejnik S., Heroizm [Heroism], [in:] Encyklopedia katolicka [Catholic Encyclopedia], Lublin, Wydawnictwo Towarzystwa Naukowego KUL, 1993, vol. VI, pp. 799800.

Penkala-Gawęcka D., Bohater kulturowy [Hero of Culture], [in:] Z. Staszczak (Ed.), Stownik etnologiczny. Terminy ogólne [Ethnological Vocabulary. General Terms],

Warszawa, Poznań, PWN, 1987, pp. 53-55.

Podbielski H. (Ed.), Literatura Grecji starożytnej [Literature of the Ancient Greece], vol. I, Lublin, Wydawnictwo Towarzystwa Naukowego KUL, 2005, pp. 329333.

Sawicki S., Tyrteusz Wielki Norwida [Norwid's Great Tyrtheus], [in:] idem, Norwida walka $z$ forma [Norwid's Fight against Form], Warszawa, PIW, 1986, pp. 121134.

Sawicki S., Wstęp [Introduction], [in:] C. Norwid, Promethidion [Promethidion], Kraków, Wydawnictwo Universitas, 1997, pp. 5-49.

Sławińska I., Makowiecki T., Za kulisami „,Tyrteja” [Behind the Scenes of “Tyrtej”], [in:] O Norwidzie pięć studiów [Five Studies on Norwid], Toruń, Księgarnia Naukowa T. Szczęsny i S-ka, 1949, pp. 33-64.

Szmydtowa Z., Miara i symbol wielkości w poezji Norwida [Measure and Symbol of Greatness in Norwid's Poetry], Warszawa, Drukarnia W. Łazarskiego, 1930, $20 \mathrm{pp}$.

Szmydtowa Z., O misteriach Cypriana Norwida [On Cyprian Norwid's Mysteria], Warszawa, Wydawnictwo Kasy im. Mianowskiego, 1932, 194 pp.

Szturc W., Mit fundacyjny narodu w ,Wandzie” Cypriana K. Norwida [The Nation Foundation Myth in Cyprian K. Norwid's "Wanda"], [in:] idem, O obrotach sfer romantycznych [On Revolution of Romantic Spheres], Bydgoszcz, Wydawnictwo Homini, 1997, pp. 127-137.

Tegnaeus H., Le héros civilisateur [The Hero of Civilization], Stockholm, Studia Ethnographica Upsaliensia, 1950, 224 pp.

Trojanowiczowa Z., Tyrteizm [Tyrtean Poetry], [in:] Stownik literatury polskiej XIX wieku [Vocabulary of 19th Century Polish Literature], J. Bachórz, A. Kowalczykowa (Eds.), Wrocław, Zakład Narodowy im. Ossolińskich Wydawnictwo, 1991, pp. 973-976. 
Trzciński Ł., Mit bohaterski w perspektywie antropologii filozoficznej i kulturowej [The Heroic Myth in the Perspective of Philosophical and Cultural Anthropology], Kraków, Wydawnictwo Uniwersytetu Jagiellońskiego, 2006, pp. 211.

Ziołowicz A., Dramat i romantyczne Ja. Studium podmiotowości w dramaturgii polskiej doby romantyzmu [Drama and the Romantic 'Me'. A Study of Subjectivity in the Polish Drama of the Romantic Period], Kraków, Wydawnictwo Universitas, 2002, pp. 291-314.

Ziołowicz A., ,"Misteria polskie”. Z problemów misteryjności w dramacie romantycznym i modernistycznym ["The Polish Mysteria". From the Problems of Mysteriousness in the Romantic and Modernistic Drama], Kraków, Wydawnictwo Universitas, 1996, pp. 48-68.

Ziołowicz A., W stronę Diogenesa. Z problemów Norwidowskiej koncepcji kultury [Towards Diogenes. From the Problems of Norwid's Conception of Culture], „Wiek XIX” [The 19th Century] 2015, pp. 359-378.

Ziołowicz A., Cypriana Norwida sztuka żywego stowa [Cyprian Norwid's Art of the Living Word], „Ruch Literacki” [Literary Movement] 2017, no. 4, p. 359-376.

Zowczak M., Mit bohaterski jako opowieść o granicach ludzkich możliwości [The Heroic Myth as a Story of Limits to Human Abilities], „Etnografia Polska” [Polish Ethnography] 1984, no. 2, pp. 243-267.

Znaniecki F., Nauki o kulturze. Narodziny i rozwój [Cultural Sciences. Their Origin and Development], trans. J. Szacki, Warszawa, PWN, 1971, 427 pp. 
